\title{
PENERAPAN METODE BALANCED SCORECARDSEBAGAI SISTEM PENGUKURAN KINERJA PADA GALANGAN KAPAL KPNDP DKI JAKARTA
}

\author{
The Application of Balanced Scorecard Method As Performance Measurement System At The KPNDP \\ Shipyard, DKI Jakarta
}

Oleh:

\author{
Izza Mahdiana Apriliani ${ }^{*}$, Sugeng H Wisudo², Budi H Iskandar², Yopi Novita \\ ${ }^{1}$ Staff Pengajar Program Studi Perikanan, FPIK Unpad \\ ${ }^{2}$ Staff Pengajar Departemen PSP FPIK IPB \\ Korespondensi: izza.mahdiana@unpad.ac.id
}

\begin{abstract}
ABSTRAK
Galangan kapal merupakan salah satu kebutuhan kapal dalam menentukan kelaikan kapal di laut. Potensi bisnis galangan kapal yang besar di wilayah Muara Angke belum dimanfaatkan dengan baik oleh pengelola perusahaan galangan kapal. Terbukti dengan keberadaan galangan kapal yang belum berkembang namun berbanding terbalik dengan jumlah kapal yang meningkat setiap tahunnya. Galangan kapal Koperasi Pegawai Negeri Dinas Perikanan (KPNDP) DKI Jakarta di Muara angke merupakan salah satu dari keempat galangan yang berada di wilayah muara angke. Galangan ini memiliki tingkat produktivitas yang tinggi dan selalu meningkat setiap tahunnya berdasarkan data produksi UPT BTPI dari tahun 2009 sampai 2012. Penilaian teknologi galangan kapal ini berada pada level semi modern. Perlu dilakukan analisis lebih lanjut terkait strategi pengembangan teknologi di galangan kapal KPNDP. Perumusan strategi perlu didahului dengan penilaian kinerja. Penilaian dilakukan dengan metode balanced scorecard. Balanced scorecard memberikan suatu kerangka kerja bagi pihak manajemen untuk menerjemahkan misi dan strategis organisasi. Analisis hasil penilaian kinerja didapatkan hasil sebesar 73. Skor ini menunjukkan bahwa galangan kapal KPNDP harus melakukan inisiatif-inisiatif (strategi) dalam pengembangan manajemen teknologinya.
\end{abstract}

Kata kunci : balanced scorecard, galangan kapal, penilaian kinerja.

\section{ABSTRACT}

The shipyard is one requirement in determining eligibility aboard ships at sea. The business potential of large shipyards in Muara Angke has not been exploited well by the manager of the company shipyard. Evidenced by the presence of the shipyard undeveloped but is inversely proportional to the number of vessels is increasing every year. Shipbuilding Civil Servants Cooperative Fisheries Agency $(K P N D P)$ in Muara Angke Jakarta is one of the four shipyards located in Angke estuary region. The shipyard has a high level of productivity and is increasing every year by UPT BTPI production data from 2009 to 2012. Assessment shipbuilding technology at the level of semi-modern. Further analysis is needed on the strategy of technology development at the shipyard KPNDP. The formulation of the strategy should be preceded by the performance appraisal. Assessment is done by the method of balanced scorecard. Balanced scorecard provides a framework for the management to translate the organization's mission and strategic. Analysis of the results showed the performance appraisal of 73. This score indicates that the shipyard KPNDP must initiatives (strategy) in the development of technology management.

Keywords: balanced scorecard, shipbuilding, performance assessment. 


\section{PENDAHULUAN}

Galangan kapal merupakan salah satu kebutuhan kapal dalam menentukan kelaikan kapal di laut. Perkembangan bisnis galangan kapal yang semakin kompetitif menyebabkan perubahan besar dalam hal persaingan, produksi dan pemasaran. Semakin banyak galangan kapal menangani kapal maka akan membantu keberhasilan aktivitas operasi penangkapan ikan. Hal ini menunjukkan bahwa galangan kapal termasuk ke dalam sektor publik yang berfokus di pelayanan jasa.

Galangan kapal yang berada di wilayah Muara Angke sebanyak empat galangan, diharapkan keempat galangan tersebut mampu menangani kapal-kapal di sekitar wilayah Muara Angke. Galangan kapal Koperasi Pegawai Negeri Dinas Perikanan (KPNDP) DKI Jakarta di Muara angke merupakan salah satu dari keempat galangan yang berada di wilayah muara angke. Galangan ini memiliki tingkat produktivitas yang tinggi dan selalu meningkat setiap tahunnya berdasarkan data produksi UPT BTPI dari tahun 2009 sampai 2012. Penilaian teknologi galangan kapal ini berada pada level semi modern (Kurniawati 2011).

Keberadaan galangan kapal di wilayah Muara Angke belum bisa mengakomodir kapal yang ada sehingga timbul antrian kapal dalam galangan. Potensi bisnis galangan kapal yang besar belum dimanfaatkan dengan baik oleh pengelola galangan kapal. Terbukti dengan keberadaan galangan kapal yang belum berkembang namun berbanding terbalik dengan jumlah kapal yang meningkat setiap tahunnya. Galangan kapal dituntut untuk terus meningkatkan kinerjanya agar dapat beroperasi dengan baik dan efisien. Jumlah kapal yang terus bertambah mengakibatkan usaha galangan kapal akan semakin kompetitif. Oleh karena itu, galangan kapal memerlukan penilaian kinerja sebagai dasar untuk menentukan efektivitas pengelolaan usahanya. Salah satu penilaian kinerja dilakukan dengan metode balanced scorecard. Balanced scorecard memberikan suatu kerangka kerja bagi pihak manajemen untuk memberikan kepuasan bagi para pelanggan. Balanced scorecard dinilai cocok untuk organisasi sektor publik karena tidak hanya menekankan pada aspek kuantitatif-finansial, tetapi menekankan juga aspek kualitatif dan nonfinansial.

Keberadaan potensi usaha galangan kapal KPNDP Muara Angke dihadapkan pada penentuan strategi dalam pengelolaan usahanya. Penyusunan rencana-rencana strategis yang akan dikembangkan didahului oleh penilaian kinerja. Penilaian kinerja akan dijadikan sebagai landasan perbaikan dan efisiensi dalam pengembangan usaha galangan kapal. Dengan demikian perlu adanya penilaian kinerja untuk merumuskan strategi pengembangan teknologi di galangan kapal KPNDP Muara Angke untuk mengembangkan galangan yang sudah berada pada level semi modern sehingga mempunyai kontribusi teknologi yang lebih besar.

\section{METODE PENELITIAN}

Penelitian dilaksanakan bulan November 2014. Perusahaan yang menjadi obyek penelitian adalah galangan kapal Koperasi Pegawai Negeri Dinas Perikanan (KPNDP) DKI Jakarta di Muara Angke. Metode penelitian yang digunakan dalam penelitian ini adalah metode survey. Data yang diperoleh selama penelitian selanjutnya diolah dengan metode Balanced scorecard dengan membagi menjadi 4 perspektif yaitu perspektif finansial, perspektif pelanggan, perspektif pembelajaran dan pertumbuhan serta perspektif bisnis internal.

Perspektif finansial diukur melalui evaluasi produksi kapal yang dilihat dari tahun 2010 sampai dengan tahun 2013 serta dilakukan pengukuran produksi tahun 2013 terhadap kapasitas galangan KPNDP dalam memperbaiki kapal berdasarkan jumlah slipway di galangan tersebut. Pengukuran kinerja pada perspektif pelanggan dilakukan dengan wawancara langsung terhadap responden. Responden pada prespektif ini yaitu pemilik kapal atau pengurus kapal yang melakukan perbaikan kapal di galangan KPNDP. Elemen paling penting dalam suatu bisnis adalah kebutuhan pelanggannya. 
Gaspersz (2003) menyebutkan fokus perspektif pelanggan untuk organisasi bisnis adalah bagaimana pelanggan memandang kinerja suatu perusahaan.

Penilaian bisnis internal terdiri dari 3 komponen yaitu proses inovasi, proses operasional dan proses pelayanan. Proses inovasi dan operasional diukur melalui waktu penyelesaian perbaikan kapal dan efektivitas waktu kerja. Proses pelayanan diukur melalui pelayanan galangan KPNDP dengan pelanggan dimulai dari kapal naik dok sampai dengan kapal turun dok. Pengukuran kinerja pada perspektif pembelajaran dan pertumbuhan didasarkan kategori kompetensi pegawai, partisipasi pegawai dan peningkatan kualitas pegawai.

\section{HASIL DAN PEMBAHASAN}

Pratiwi (2010) memaparkan beberapa keunggulan yang dimiliki oleh balanced scorecard, yaitu: (1) membuka peluang untuk memanfaatkan secara optimum alat manajemen dalam men-dongkrak kemampuan perusahaan dalam menghasilkan kinerja keuangan; (2) adanya peluang untuk melipatgandakan kinerja keuangan perusahaan; (3) menjadikan sistem manajemen strategi sekarang berbeda dengan sistem manajemen strategi dalam manajemen tradisional; dan (4) mampu menghasilkan rencana strategik yang memiliki karakteristik, strategik, komprehensif, koheren, seimbang dan terukur. Penilaian kinerja dari keempat perspektif di balanced scorecard diharapkan mampu memberikan keunggulan dan hasil yang dapat meningkatkan kinerja pada galangan KPNDP untuk kegiatan perbaikan kapal penangkap ikan. Hal ini dikarenakan galangan kapal yang melayani perbaikan kapal penangkap ikan yang berbahan dasar kayu semakin mengalami penurunan yang berbanding terbalik dengan keberadaan kapal penangkap ikan yang semakin meningkat. Dengan demikian perlu dilakukan penilaian kinerja pada galangan kapal KPNDP untuk meningkatkan kinerja dalam penerimaan perbaikan kapal di Indonesia khususnya di wilayah Muara Angke.

\section{Perspektif Finansial}

Menurut Gaspersz (2003) dalam membangun suatu balanced scorecard, unit-unit bisnis harus dikaitkan dengan tujuan finansial yang berkaitan dengan strategi perusahaan. Tujuan finansial ini berperan sebagai fokus bagi tujuan-tujuan strategis dalam menjalankan sebuah perusahaan. Ukuran yang dipilih dalam menjelaskan perpektif finansial dilihat dari produktivitas galangan KPNDP dalam melakukan perbaikan kapal setiap tahunnya.

Berdasarkan data produksi galangan KPNDP pada tahun 2010 sampai tahun 2013, galangan kapal KPNDP cenderung mengalami peningkatan produktivitas (Gambar 1). Penurunan produktivitas terjadi pada tahun 2011 dikarenakan galangan KPNDP melakukan pembangunan slipway sehingga kegiatan perbaikan kapal terhambat.

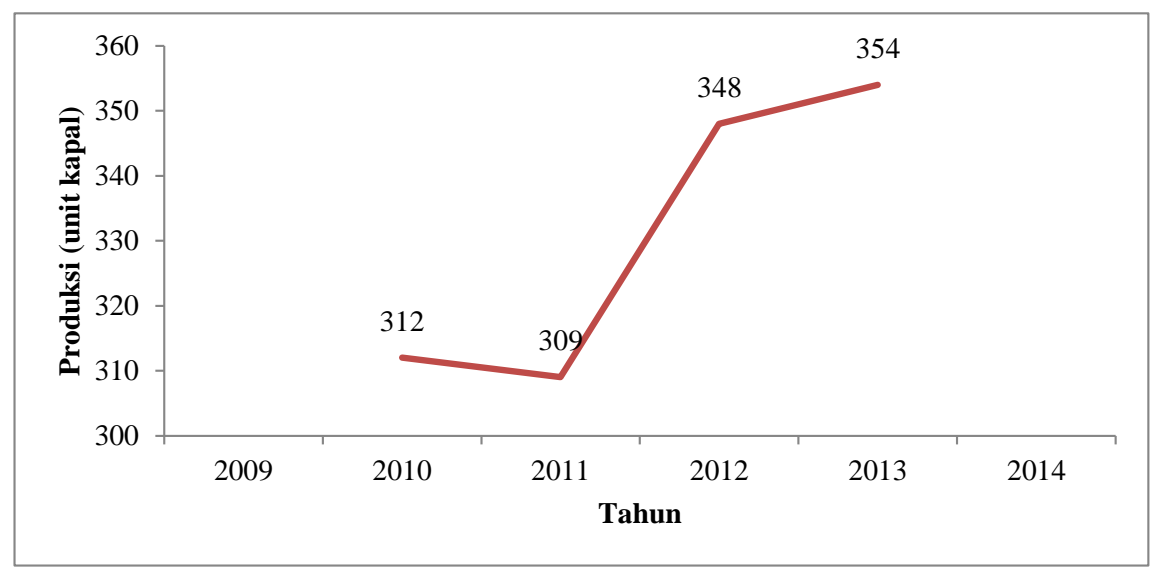

Sumber: UPT BTPI (2013) diolah

Gambar 1 Fluktuasi produksi galangan kapal KPNDP tahun 2010-2013 
Peningkatan produktivitas galangan KPNDP seiring dengan keberadaan slipway yang mampu menampung jumlah kapal di galangan. Tahun 2013 galangan kapal KPNDP memiliki slipway berjumlah 7 unit yang memiliki kapasitas berbeda. Slipway dengan kapasitas 100-200 GT berjumlah 4 unit (mampu menampung 4 kapal berukuran 100-200 GT) dan slipway berkapasitas dibawah 100 GT berjumlah 3 unit ( 2 unit mampu menampung 2 kapal sekaligus dan 1 unit hanya mampu menampung 1 kapal). Hal ini menunjukkan bahwa galangan KPNDP mampu menerima kurang lebih 27 unit kapal perbulannya, dengan asumsi perbaikan kapal yang dilakukan adalah perbaikan kapal ringan (lama waktu perbaikan kapal ringan 7 hari kerja). Jika setiap kapal membayar biaya galangan rata-rata Rp 6.000.000,00 maka penerimaan yang diperoleh galangan KPNDP dalam satu bulan sebesar Rp $162.000 .000,00$.

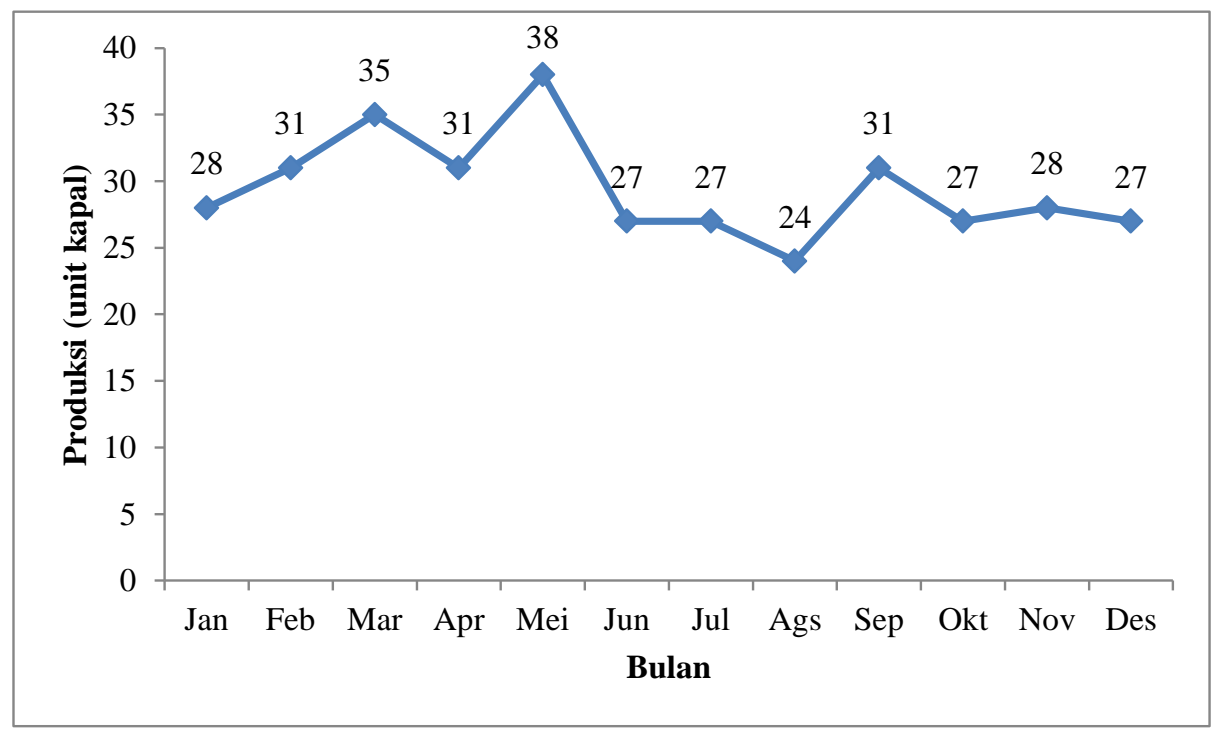

Sumber: UPT BTPI (2013) diolah

Gambar 2 Flutuasi produksi galangan kapal KPNDP tahun 2013

Tahun 2013 mengalami produktivitas yang fluktuatif jika dilihat dari produktivitas perbulannya. Berdasarkan produksi tahun 2013 (Gambar 2), produksi galangan KPNDP sudah mendekati kapasitas maksimalnya. Namun terjadi kelebihan muatan pada bulan Mei yaitu sebanyak 38 kapal. Banyaknya kapal yang melakukan perbaikan pada bulan Mei 2013 membuat pihak galangan bekerja keras dalam mengatur posisi kapal dalam slipway. Kondisi ini memaksa galangan untuk dapat meningkatkan fasilitas demi melayani kebutuhan kapal. Terlihat pada ketersediaan lahan di sekitar galangan KPNDP ini masih memungkinkan untuk diusulkannya penambahan jumlah slipway. Saat ini galangan KPNDP memiliki slipway sebanyak 7 unit dan dalam proses peningkatan sebanyak 4 unit. Peningkatan jumlah slipway ini bertujuan untuk meningkatkan produktivitas galangan KPNDP dalam memperbaiki kapal penangkap ikan. Peningkatan produktivitas seiring dengan peningkatan penerimaan suatu perusahaan seperti yang digambarkan oleh Gaspersz (2003) yang membenarkan bahwa hubungan sebab akibat dalam perspektif finansial. Oleh karena itu, peningkatan jumlah slipway diharapkan meningkatkan produktivitas galangan sehingga dapat meningkatkan pula penerimaan galangan KPNDP ini.

Peningkatan produktivitas dapat dilakukan dengan cara penerapan waktu kerja efektif. Hasil dari analisis dan efektivitas jaringan kerja (Apriliani et al. 2014) dapat disimpulkan bahwa waktu kerja efektif dapat dilakukan untk menyelesaikan perbaikan kapal ringan selama 5 hari. Menerapkan waktu kerja efektif perbaikan kapal ringan ini dapat meningkatkan satu hingga dua kapal per slipway. Peningkatan penerimaan yang dapat diterima galangan apabila menerapkan waktu kerja efektif ini kira-kira sebesar Rp 24.000.00,00. Dengan demikian, penerapan waktu kerja efektif perbaikan kapal ringan akan meningkatkan penerimaan untuk pihak galangan. 


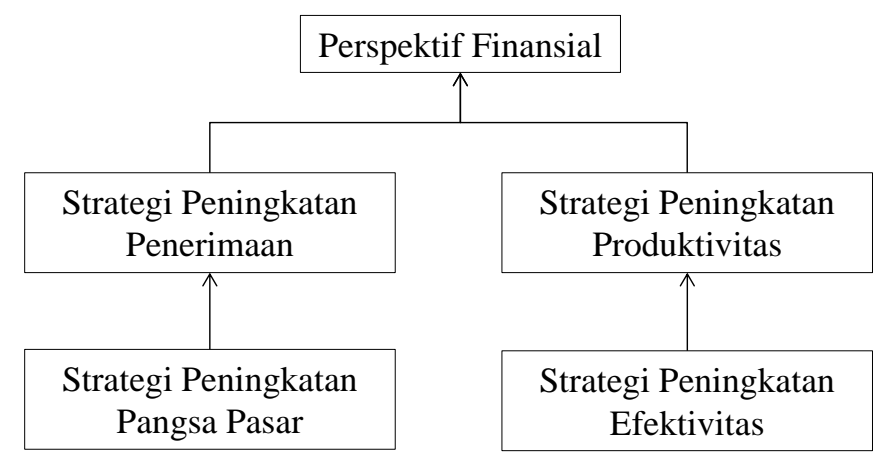

Sumber: Gaspersz (2003)

Gambar 3 Diagram keterkaitan hubungan sebab-akibat perspektif finansial

\section{Perspektif Pelanggan}

Elemen paling penting dalam kehidupan perusahaan adalah aspek pelanggan (Pratiwi 2010). Pengukuran kinerja pada perspektif ini dikategorikan dalam 5 kelompok pertanyaan (Yuniarta 2009).

\section{Kelompok tangibility}

Tanggapan pelanggan terhadap tampilan fisik kantor pelayanan galangan kapal KPNDP ditinjau dalam 3 aspek yaitu (1) kemudahan dalam menjangkau lokasi galangan serta keamanan lingkungan galangan; (2) penampilan kantor galangan dan kebersihan ruang tunggu; dan (3) aspek ketersediaan fasilitas kantor dan informasi pelayanan di ruang tunggu. Tanggapan pelanggan dari masing-masing aspek sebesar $76,9 \%$ menyatakan puas, $100 \%$ yang menyatakan puas serta $53,8 \%$ cukup puas.

Analisis tingkat kepuasan pelanggan pada kelompok tangibility mendapatkan skor persepsi ratarata lebih rendah dibandingkan dengan skor harapan pelanggan. Hal ini menunjukkan bahwa pelayanan dalam kelompok tangibility belum memenuhi harapan pelanggan dan berada pada tingkat kepuasan $82,2 \%$. Perlu dilakukan perbaikan mengenai aspek yang masih memiliki nilai tidak puas yaitu informasi perkembangan perbaikan kapal yang diharapkan pelanggan.

\section{Kelompok reliability}

Tanggapan pelanggan terhadap pelayanan dari galangan kapal KPNDP ditinjau dari 3 aspek. Kecepatan dalam penyelesaian perbaikan kapal mendapatkan respon sebesar $84,6 \%$ merasa sangat puas dan 15,4\% merasa puas. Kecepatan pelayanan galangan KPNDP dalam menangani kapal yang masih terjadi kerusakan mendapatkan respon pelanggan sebesar $100 \%$ yang menyatakan puas. Kecepatan dan ketanggapan karyawan dalam memberikan pelayanan memperoleh respon pelanggan sebesar $15,4 \%$ merasa sangat puas, $53,8 \%$ merasa puas dan $30,8 \%$ merasa cukup puas.

Analisis kepuasan pelanggan pada kelompok reliability memiliki skor persepsi rata-rata lebih rendah dibandingkan dengan skor harapan pelanggan. Kondisi ini menunjukkan bahwa pelayanan pada kelompok reliability belum memenuhi harapan pelanggan dan hanya mencapai tingkat kepuasan pelanggan sebesar $84 \%$. Nilai tersebut dianggap masih perlu ditingkatkan lagi pelayanan di galangan KPNDP untuk memenuhi harapan pelanggan.

\section{Kelompok responsiviness}

Tanggapan pelanggan terhadap ketanggapan galangan KPNDP dalam memberikan pelayanan terhadap pelanggan dilihat dari 2 aspek. Aspek pertama yaitu respon galangan dalam menanggapi pengajuan perawatan kapal mencapai nilai $100 \%$ yang menyatakan sangat puas. Aspek kedua yaitu respon galangan dalam menanggapi kesalahan dalam proses perbaikan kapal mendapatkan nilai $100 \%$ yang menyatakan puas. 
Analisis tingkat kepuasan pelanggan pada kelompok responsiveness mendapatkan skor persepsi rata-rata pelanggan lebih kecil dari skor harapan pelanggannya. Hal ini menunjukkan bahwa pelayanan pada kelompok ini belum memenuhi harapan pelanggan. Namun tingkat kepuasan pelanggan mencapai nilai sebesar $91,8 \%$ dan hampir mendekati harapan pelanggan.

\section{Kelompok assurance}

Tanggapan pelanggan terhadap jaminan mengenai kemampuan, kesopanan, keahlian dan sifat dapat dipercaya dari pegawai galangan KPNDP ditinjau dari 6 aspek yaitu (1) keramahan pegawai dalam memberikan pelayanan; (2) aspek pengetahuan pegawai; (3) kesopanan, kedisiplinan dan kebersihan pegawai dalam memberikan pelayanan; (4) jaminan ketepatan waktu perbaikan kapal; (5) aspek kepedulian pegawai dalam memberikan pelayanan; dan (6) dan keterampilan pegawai.

Analisis tingkat kepuasan pelanggan pada kelompok assurance menghasilkan skor persepsi ratarata pelanggan lebih rendah dari skor harapan pelanggannya. Hal ini menunjukkan bahwa pelayanan pada kelompok assurance belum memenuhi harapan pelanggannya. Tingkat kepuasan pelanggan mencapai nilai sebesar $83 \%$ sehingga perlu dilakukan peningkatan pelayanan khususnya yang bersifat kedisiplinan pegawai agar sesuai dengan harapan pelanggan.

\section{Kelompok emphaty}

Tanggapan pelanggan terhadap kemudahan dalam meminta pelayanan galangan KPNDP dan komunikasi bagi kebutuhan pelanggan dinilai dari 5 aspek. Adanya prosedur yang cepat, sederhana, mudah dan jelas di setiap pelayanan memberikan tanggapan pelanggan sebesar 38,5\% yang menyatakan sangat puas dan $61,5 \%$ yang menyatakan puas. Kemudahan komunikasi secara langsung mendapat tanggapan pelanggan sebesar $100 \%$ yang menyatakan sangat puas. Kemudahan informasi melalui media mendapatkan hasil sebesar 38,5\% merasa puas dan 61,5\% merasa cukup puas. Aspek ketepatan waktu dalam memberikan informasi mendapatkan respon pelanggan sebesar 100\% yang menyatakan puas terhadap pelayanan ini.

Analisis tingkat kepuasan pelanggan pada kelompok emphaty mendapatkan skor persepsi ratarata pelanggan lebih kecil dari skor harapan pelanggannya. Hal ini menunjukkan bahwa pelayanan pada kelompok ini belum memenuhi harapan pelanggan. Tingkat kepuasan pelanggan mencapai nilai sebesar $87,75 \%$ dan hampir mendekati harapan pelanggan, namun perlu ditingkatkan lagi agar memenuhi harapan pelanggan.

\section{Perspektif Bisnis Internal}

Kaplan dan Norton (1996) membagi bisnis internal kedalam 3 komponen, yaitu proses inovasi, proses operasional dan proses pelayanan. Proses inovasi merupakan salah satu kritikal proses, dimana efisiensi dan efektifitas serta ketepatan waktu dari proses inovasi ini akan mendorong terjadinya efisiensi proses penciptaan nilat tambah. Proses operasi adalah proses untuk membuat dan menyampaikan produk/jasa. Aktivitas di dalam proses operasi terbagi kedalam dua bagian, pertama proses pembuatan produk dan proses penyampaian produk ke pelanggan.

Pengukuran kinerja dalam proses inovasi dan operasi ditinjau dari aspek waktu penyelesaian perbaikan kapal dan efisiensi waktu kerja. Penyelesaian perbaikan kapal dianalisis dengan metode critical path method untuk mengetahui jalur kritis dimana galangan tidak boleh terlambat dalam melakukan pekerjaan pada jalur kritis (Soeharto, 1997). Kegiatan yang terdapat pada jalur kritis harus dilakukan tepat pada waktunya, karena apabila salah satu kegiatan terjadi keterlambatan maka akan mempengaruhi pekerjaan lainnya. Keterlambatan pada perbaikan kapal ringan salah satunya diakibatkan oleh keadaan cuaca yang kurang mendukung dan menyebabkan lama waktu proses pengeringan cat. Berdasarkan hal tersebut, pihak galangan KPNDP mengantisipasi kemunduran waktu kerja dengan cara pengadaan waktu lembur agar pekerjaan perbaikan dapat diselesaikan tepat pada waktunya. Keterlambatan pada perbaikan kapal berat diakibatkan oleh waktu tunggu (slack) yang 
lama/besar dikarenakan perbaikan mesin. Masalah yang sering terjadi dalam perbaikan kapal berat ini adalah kemampuan bengkel dalam memperbaiki kerusakan mesin kapal dan keterbatasan spare part yang sebagaian besar tidak tersedia di Indonesia.

Waktu efektif perbaikan kapal ringan dapat ditempuh selama 5 hari. Waktu ini bisa dilakukan lebih cepat dibandingkan dengan waktu yang dialokasikan oleh pihak galangan yaitu selama 7 hari (Apriliani et al. 2014). Efektivitas kerja perbaikan kapal dapat ditingkatkan lagi melalui pengawasan yang lebih baik serta memberikan motivasi kepada pegawai untuk bekerja lebih giat lagi dan tidak membuang waktu untuk kegiatan yang tidak efektif. Waktu efektif perbaikan kapal berat dilakukan selama 10 hari. Waktu ini tidak memiliki perbedaan dengan waktu yang dialokasikan galangan.

Proses pelayanan merupakan jasa pelayanan galangan KPNDP kepada pemilik kapal. Pengukuran kinerja ini berkaitan dengan perspektif pelanggan, yaitu apakah galangan KPNDP ini telah memenuhi harapan pelanggan dengan menggunakan tolak ukur kualitatif seperti yang dilakukan pada perspektif pelanggan. Hasil dari pengukuran ini masih perlu ditingkatkan lagi untuk memenuhi harapan pelanggan galangan KPNDP.

\section{Perspektif Pembelajaran dan Pertumbuhan}

Penilaian kinerja pada perspektif ini didasarkan pada kategori kompetensi pegawai, partisipasi pegawai dan peningkatan kualitas pegawai. Kategori kompetensi pegawai diukur melalui 8 aspek. Tanggapan pegawai merasa puas dan cukup puas dengan pemahaman fasilitas dan fasilitas yang tersedia di galangan KPNDP. Fasilitas galangan kapal dinilai sudah mendukung dengan semua aktivitas di galangan ini. Tingkat kepuasan dalam menangani pelanggan memiliki nilai sebesar $90,63 \%$ yang merasa puas dan 9,38\% merasa sangat puas. Hal ini menunjukkan tingginya loyalitas yang diberikan pegawai KPNDP untuk memenuhi kebutuhan pelanggan. Aspek pelatihan untuk meningkatkan pengetahuan, seminar yang diadakan UPT BTPI serta kesempatan untuk mengikuti pelatihan dinilai sangat tidak puas sebanyak $87,5 \%$. Hal ini disebabkan oleh tidak adanya realisasi pengadaan pelatihan oleh UPT BTPI yang seharusnya dijadwalkan rutin per tahun, namun kenyataannya tidak ada pelatihan tersebut. Berdasarkan informasi di lapangan, pelatihan pernah dilakukan pada tahun 2011 namun hanya pada level manajer saja. Seharusnya hal ini tidak terjadi agar kebutuhan kompetensi pegawai dapat dilaksanakan dengan baik.

Pengukuran kinerja pada kategori partisipasi pegawai ditinjau berdasarkan partisipasi pegawai dalam bekerjasama, kesempatan menjadi bagian penting, kesibukan sepanjang waktu kerja dan kesempatannya dalam mengembangkan karir. Berdasarkan pengukuran pada kategori ini didapatkan hasil puas dan cukup puas untuk melakukan kesempatan bekerjasama, kesempatan menjadi bagian penting dan kesibukan sepanjang waktu kerja. Hal ini sangat berpengaruh terhadap suasana kerja di galangan KPNDP. Beberapa pegawai memberikan respon tidak puas dan sangat tidak puas terhadap kesempatannya mengembangkan karir dikarenakan tidak adanya pelatihan rutin yang diberikan oleh UPT BTPI.

Kategori pengukuran peningkatan kualitas pegawai menyatakan tidak puas pada aspek pengembangan karir pegawai dan penghargaan oleh galangan karena mencapai target kerja. Upaya pengembangan karir seharusnya dilakukan oleh UPT BTPI secara rutin per tahunnya, sehingga dapat meningkatkan kualitas sumberdaya galangan. Perlunya penghargaan untuk pegawai dalam upaya pencapaian target kerja. Tanggapan pegawai merasa puas melihat dari profesionalisme galangan untuk meningkatkan kualitas perbaikan kapalnya.

\section{Analisis Hasil Kinerja Keseluruhan}

Keempat perspektif balanced scorecard akan terintegrasi dalam sistem manajemen. Integrasi dari keempat perspektif menggambarkan hubungan sebab-akibat, dimana faktor sebab terdiri dari perspektif pembelajaran dan pertumbuhan serta perspektif bisnis internal. Faktor akibat terdiri dari perspektif pelanggan dan perspektif finansial. 
Analisis hasil kinerja keseluruhan mencakup ke empat perspektif yaitu perspektif finansial, perspektif pelanggan, perspektif bisnis internal serta perspektif pembelajaran dan pertumbuhan. Hasil kinerja dari ke empat perspektif dapat di lihat pada Tabel 1. Penilaian setiap perspektif diberikan skor dari 1 sampai 5. Skor ini diartikan sebagai berikut:

Tabel 1 Hasil pengukuran kinerja keseluruhan

\begin{tabular}{|c|c|c|c|c|c|c|c|}
\hline No. & & Aspek yang diukur & $\begin{array}{c}\text { Hasil } \\
\text { pengukuran }\end{array}$ & $\begin{array}{c}\text { Realisasi } \\
(\mathrm{R})\end{array}$ & $\begin{array}{c}\text { Target } \\
(\mathrm{T})\end{array}$ & $\begin{array}{l}\text { Bobot } \% \\
\text { (B) }\end{array}$ & $\begin{array}{c}\text { Skor } \\
\left(\mathrm{R} / \mathrm{T}^{*} \mathrm{~B}\right)\end{array}$ \\
\hline \multirow[t]{4}{*}{1} & Pers & ektif Finansial & & & & & \\
\hline & (1) & $\begin{array}{l}\text { Tingkat produktivitas 2010- } \\
2013\end{array}$ & Sangat baik & 5 & 5 & 10 & 10 \\
\hline & (2) & Produksi tahun 2013 & Baik & 4 & 5 & 10 & 8 \\
\hline & \multicolumn{2}{|c|}{ Skor Perspektif Finansial } & & 9 & 10 & 20 & 18 \\
\hline \multirow[t]{3}{*}{2} & \multicolumn{2}{|c|}{ Perspektif Pelanggan } & & & & & \\
\hline & (1) & $\begin{array}{l}\text { Tingkat kepuasan } \\
\text { pelanggan }\end{array}$ & Baik & 4 & 5 & 20 & 16 \\
\hline & \multicolumn{2}{|c|}{ Skor Perspektif Pelanggan } & & 4 & 5 & 20 & 16 \\
\hline \multirow[t]{3}{*}{3} & \multicolumn{2}{|c|}{ Perspektif Bisnis Internal } & & & & & \\
\hline & (1) & Inovasi dan operasioanl & Cukup & 3 & 5 & 15 & 9 \\
\hline & (2) & Pelayanan & Baik & 4 & 5 & 15 & 12 \\
\hline \multicolumn{3}{|c|}{ Skor Perspektif Bisnis Internal } & & 7 & 10 & 30 & 21 \\
\hline \multirow[t]{4}{*}{4} & \multicolumn{2}{|c|}{$\begin{array}{l}\text { Perspektif Pembelajaran dan } \\
\text { Pertumbuhan }\end{array}$} & & & & & \\
\hline & (1) & Kompetensi pegawai & Cukup & 3 & 5 & 10 & 6 \\
\hline & (2) & Partisipasi pegawai & Baik & 4 & 5 & 10 & 8 \\
\hline & (3) & Peningkatan kualitas & Kurang & 2 & 5 & 10 & 4 \\
\hline \multicolumn{3}{|c|}{$\begin{array}{l}\text { Skor Perspektif Pembelajaran dan } \\
\text { Pertumbuhan }\end{array}$} & & 9 & 15 & 30 & 18 \\
\hline & & TOTAL & & 29 & 40 & 100 & 73 \\
\hline
\end{tabular}

Keterangan:

$1=$ buruk $\quad 4$ = baik

$2=$ kurang $\quad 5$ = sangat baik

$3=$ cukup

Hasil kinerja pada setiap perspektif diberikan bobot. Pembobotan tersebut berdasarkan faktor sebab yaitu masing-masing $30 \%$ dan faktor akibat masing-masing memiliki bobot $20 \%$, sehingga total bobot maksimal $100 \%$. Hasil analisis pengukuran kinerja secara keseluruhan menunjukkan nilai sebesar 73. Kondisi ini berada pada skor kuning berdasarkan dashboard balanced scorecard (Sudirman 2013). Skor ini menunjukkan bahwa galangan kapal KPNDP harus melakukan inisiatif-inisiatif (strategi) dalam pengembangan manajemen teknologinya.

\section{KESIMPULAN DAN SARAN}

\section{Kesimpulan}

Berdasarkan analisis penilaian kinerja, maka dapat disimpulkan bahwa perpektif bisnis internal menjadi unsur penting dalam pengelolaan usaha ini dikarenakan bisnis internal memiliki rasio nilai tertinggi dibandingkan dengan perspektif lain. Hal yang harus diperhatikan dan perlu dikembangkan yaitu dilihat dari perpektif kepuasan pelanggan diantaranya informasi perkembangan perbaikan kapal yang terkait dengan antrian kapal. Secara keseluruhan penilaian kinerja didapatkan hasil sebesar 73 
atau berada pada wilayah sedang sehingga perlu dilakukan perbaikan-perbaikan agar kinerja galangan kapal KPNDP menjadi lebih baik.

Saran

Perlu dilakukan rumusan strategi bagi galangan kapal KPNDP untuk dapat diimplementasikan sebagai suatu perbaikan kinerja galangan.

\section{DAFTAR PUSTAKA}

Apriliani IM, Wisudo SH, Iskandar BH dan Novita Y. 2014. Jaringan kerja dan efektivitas perbaikan kapal di Galangan KPNDP DKI Jakarta, Muara Angke. Marine Fisheries. 5(1).

Gaspersz V. 2003. Sistem Manajemen Kinerja Terintegrasi: Balanced Scorecard dengan Six Sigma untuk Organisasi Bisnis dan Pemerintah. Jakarta (ID): Gramedia. $324 \mathrm{hlm}$.

Kurniawati VR. 2011. Analisis penilaian tingkat teknologi pada galangan kapal di sekitar PPI Muara Angke. Jurnal Buletin PSP. 19(1):29-38.

Kaplan RS, Norton DP. 1996. Balanced scorecard: Menerapkan Strategi Menjadi Aksi. Jakarta (ID): Erlangga.

Pratiwi U. 2010. Balanced scorecard dan manajemen strategik. Jurnal Manajemen dan Akutansi. 11(2) :166-174.

Soeharto I. 1997. Manajemen Proyek: Dari Konseptual Sampai Operasional. Jakarta (ID): Erlangga.

Sudirman I. 2013. Topik-Topik Riset Manajemen Strategi. Bogor (ID): IPB Press.

[UPT BTPI] Unit Pelaksana Teknis Balai Teknologi Penangkapan Ikan. 2013. Data Produksi Dok di Lingkungan UPT BTPI Muara Angke Jakarta. Jakarta (ID): UPT BTPI.

Yuniarta S. 2009. Strategi Pengembangan Kinerja Perizinan Usaha Penangkapan Ikan [tesis]. Bogor (ID). Institut Pertanian Bogor. 